\title{
MANAJEMEN PENYIARAN PROGRAM BAHASA DAERAH RADIO REPUBLIK INDONESIA SINTANG
}

\author{
Irwan S, Kaja \\ Fakultas Ilmu Sosial dan Ilmu Politik Universitas Kapuas Sintang \\ J1.JC.Oevang Oeray Sintang Kalimantan Barat \\ Email : kajaunka@gmail.com
}

\begin{abstract}
Abstrak : Manajemen Penyiaran Program Bahasa Daerah Radio Republik Indonesia Sintang dalam pelaksanaan penyiaran terlebih dahulu melakukan perencanaan penyiaran khususnya penyiaran bahasa daerah dilakukan koordinasi pengasuh acara dengan koordinator (kasubsi perencanaan program) di sesuaikan dengan kebutuhan masyarakat atau pendengar sehingga menarik, baik dari segi isi siaran maupun sasaran penyiaran. Pengorganisasian penyiaran Bahasa Daerah, secara organisasi dilaksanakan Radio Republik Indonesia berdasarkan pembagian tugas. Pelaksanaan penyiaran tersebut berdasarkan perencanaan yang telah di tentukan maupun jadwal pelaksanaan siaran, pengawasan penyiaran dilakukan oleh Kasi Penyiaran berkaitan dengan isi siaran maupun ketentuan penyiaran, pengawasan tersebut juga dilakukan oleh pemerhati penyiaran maupun oleh masyarakat sebagai pendengar dapat memberikan saran dan masukan atas siaran yang di sajikan Radio Republik Indonesia.
\end{abstract}

Kata Kunci : Manajemen, Penyiaran, Program

Manajemen pengelolaan penyiaran program Radio Republik Indonesia (RRI) sebagai lembaga penyiaran publik dalam pelaksanaannya berdasarkan kepada Undang-Undang Nomor 32 Tahun 2002 Tentang Penyiaran. Peraturan Pemerintah (PP) PP Nomor 11 Tahun 2005 Tentang Lembaga Penyiaran Publik (LPP), adalah lembaga penyiaran yang bersifat independen, netral, tidak komersial dan berfungsi melayani kepentingan publik. Untuk mencapai tujuan ini, Lembaga Penyiaran Publik harus dikelola dengan baik sesuai dengan fungsi manajemen. Selain itu Radio Republik Indonesia (LPP RRI) adalah milik Pemerintah yang netral, independen dan terpercaya sehingga RRI membuka diri kepada masyarakat yang ingin mengisi acara di RRI, hal ini menunjukan bahwa RRI merupakan ruang public untuk menyampaikan informasi secara luas pada masyarakat secara keseluruhan, oleh karena itu, RRI sangat berpengaruh dalam penyelenggaraan pemerintahan negara terhadap pembangunan melalui berbagai faktor, baik faktor internal maupun faktor eksternal dari pemerintahan tersebut. Faktor eksternal mencakup kondisi dinamis dalam masyarakat yang membawa berbagai tuntutan baru sehingga diperlukan adanya kualitas pelayanan yang semakin baik. Sedangkan faktor internal mencakup berbagai hal diantaranya adalah adanya organisasi dan manajemen pemerintahan yang efektif, efisien dan akuntabel. Konsekuensi logis dari kondisi ini adalah selain mampu memahami perkembangan dinamis yang ada ditengah masyarakat sehingga mengenali berbagai aspirasi dan kebutuhan yang berkembang tetap juga membutuhkan informasi dalam manajemen pemerintahan yang baik, efisien, efektif dan akuntabel. Program siaran menjadi sangat penting sehingga di perlukan pengaturan agar menjadi teratur pelaksanaan siaran yang dimaksud, pelaksanaan penyiaran Bahasa Daerah yang disiarkan RRI termasuk salah satu program yang mengisi acara dalam rangka memperkenalkan budaya dan tradisi daerah masing-masing khususnya di Kabupaten Sintang, namun demikian, bahwa tidak semua bahasa daerah dapat tertampung mengingat padatnya jadwal siaran sehingga pelaksanaan siaran bahasa daerah dayak lebang dan dayak desa tidak dapat disiarkan atau ditayang setiap minggu karena bergantian waktu siaran.

Dengan demikian, terdapat kelemahan dari manajemen siaran, selain itu kelemahan lainnya adalah bahwa penyiaran program bahasa daerah tidak dilakukan melalui pelatihan sehingga kesannya yang mengisi acara tersebut asal ada saja karena tidak di bekali dengan skill yang berkaitan dengan penyiaran serta tidak adanya persyaratan khusus dalam penyiaran yang relevan. Manajemen penyiaran berkaitan erat dengan pelayanan publik, sebab penyiaran dilaksanakan untuk kepentingan publik dan ditujukan pada publik selaku pendengar, dengan demikian semua berita dapat di akses publik serta memotivasi masyarakat untuk terlibat dalam permasalahan publik. Radio Republik Indonesia (RRI) berkomitmen melakukan penyiaran publik serta memelihara program acaranya demi melayani kepentingan masyarakat agar penyiaran dapat menjangkau warga masyarakat di pedesaan sehingga mampu mendorong integrasi sosial dan memberikan informasi pada masyarakat. Radio Republik Indonesia sebagai sebuah layanan unik yang menyajikan akses universal terhadap 
informasi dan pengetahuan lewat isi program yang berkualitas dan beragam. Berdasarkan paparan di atas, bahwa pertanyaan yang diajukan adalah Bagaimanakah manajemen penyiaran program Bahasa Daerah Radio Republik Indonesia Sintang? Menurut Robbins dan Mary Coulter dalam (Rusdiana, 2014 : 112) bahwa,"Manajemen adalah proses pengorganisasian kegiatan-kegiatan pekerjaan sehingga pekerjaan tersebut terselesaikan secara efektif, efisien, dan melalui orang lain.” Dengan demikian bahwa manajemen merupakan sebuah proses yang dijabarkan dalam empat fungsi secara keseluruhan mencakup perencanaan, pengorganisasian, pelaksanaan, dan pengawasan. Berdasarkan definisi yang dikemukakan di atas, maka manajemen penyiaran Program Bahasa Daerah RRI berangkat dari pengertian dan fungsi manajemen, sebab tidak ada sebuah organisasi yang tidak melakukan perencanaan dan tidak ada organisasi yang tidak melaksanakan fungsi manajemen, oleh karena itu, dilakukan serangkaian aktivitas berkaitan dengan fungsi manajemen tersebut. Jadi perencanaan adalah sekelompok aktivitas dan menentukan berbagai aktivitas yang harus dilakukan kapan dan oleh siapa, selanjutnya perencanaan yang baik bukan hanya terletak pada kemampuan merencanakan tetapi pada kemampuan melaksanakannya. Pengelolaan stasiun penyiaran membuat keputusan harus menetapkan tujuan terlebih dahulu. Dalam menetapkan tujuan, pengelola stasiun penyiaran harus mengacu kepada pernyataan misi (mission statement) organisasi. Pernyataan misi berisi satu atau beberapa kalimat singkat dan jelas yang menjadi acuan atau standar dalam melaksanakan kegiatan.

Perencanaan merupakan kegiatan untuk menetapkan tujuan yang akan dicapai atau yang dilaksanakan beserta cara-cara untuk mencapai tujuan tersebut. Dengan demikian perencanaan berarti memperkirakan apa yang dilaksanakan.

Undang-Undang Republik Indonesia Nomor 32 Tahun 2002 Tentang Penyiaran. Selanjutnya di atur dalam Peraturan Pemerintah Republik Indonesia Nomor 12 Tahun 2005 Tentang Lembaga Penyiaran Publik Radio Republik Indonesia. Berdasarkan Peraturan Pemerintah tersebut pada pasal (1) ayat (2) dan (3) menjelaskan bahwa : Pasal (2) Lembaga Penyiaran Publik adalah lembaga penyiaran yangberbentuk badan hukum yang didirikan oleh negara, bersifatindependen, netral, tidak komersial, dan berfungsi memberikanlayanan untuk kepentingan masyarakat. Pasal (3) Lembaga Penyiaran Publik Radio Republik Indonesia adalah Lembaga Penyiaran Publik yang menyelenggarakan kegiatan penyiaran radio, bersifat independen, netral, tidak komersial, dan berfungsi memberikan layanan untuk kepentingan masyarakat. Dengan demikian program penyiaran dilaksanakan berdasarkan kebutuhan maupun kepentingan masyarakat sehingga acara tersebut perlu dilaksanakan atau di eksekusi.

Menurut Morrisan (2009:302), mengatakan bahwa, "Eksekusi program merupakan kegiatan mencakup penayangan program sesuai dengan rencana yang sudah ditetapkan. Penayangan program harus ditata dan disusun sesuai dengan jadwal siaran baik itu program siaran on air maupun off air." Presman dan Asron (dalam Jeffrey, 1991: 295) mendefinisikan bahwa “(1). Pelaksanaan mungkin dapat dipandang sebagai sebuah proses interaktif antara suatu perangkat tujuan dan tindakan yang mampu untuk meraihnya; (2). Pelaksanaan atau penerapan program dengan demikian telah menjadi suatu jaringan yang nampak; (3). Pelaksanaan adalah kemampuan untuk membentuk hubungan yang lanjut dalam rangkaian sebab akibat yang menghubungkan tindakan dengan tujuan. Pendapat di atas menunjukkan bahwa pelaksanaan itu adalah melaksanakan suatu kebijakan atau program dimana akibat tersebut itu akan berdampak atau berpengaruh, sehingga akan membawa suatu dampak terhadap tatanan kehidupan dalam suatu masyarakat.

Syafii (2011 : 101) mengatakan," Pelaksanaan kerja adalah suatu tindakan untuk mengusahakan agar seluruh anggota kelompok berkenan berusaha mencapai sasaran agar sesuai dengan perencanaan managerial dan usaha-usaha organisasi."Sesuai dengan hal terasebut maka pelaksanaan suatu kegiatan atau aktivitas melaksanakan program yang sudah di buat dan di rencanakan dapat dikerjakan dengan baik. Demikian juga pelaksanaan siaran Radio Republik Indonesia berdasarkan buku petunnjuk teknis penyelenggaraan siaran radio mobile program (Program Radio Bergerak) pada LPP RRI (2011 :30) Seluruh pelaksanaan kegiatan ini, dipandu oleh Pengarah Acara yang terus menerus berkoordinasi dengan produser dan kerabat kerja lainnya.

Program Radio Bergerak atau Radio Mobile Program adalah sebuah pola sajian atau pendekatan yang digunakan dalam siaran, melalui perangkat siaran yang dapat bergerak/berpindah dari satu titik ke titik lainnya dalam satu rangkaian siaran.Program Radio Bergerak adalah bagian dari rangkaian acara siaran suatu stasiun penyiaran. Berdasarkan hal tersebut di atas, berarti semua kegiatan pelaksanaannya dilakukan koordinasi sehingga persepsinya sama dalam penentuan pekerjaan yang di jadikan dasar acuan pelaksanaannya. Menurut Syamsi (1998 : 96) penggerakan merupakan usaha untuk menciptakan iklim kerja sama di antara staf pelaksana program 
sehingga tujuan organisasi dapat tercapai secara efektif dan efisien. Sesuai dengan hal tersebut dalam mendefinisikan fungsi manajemen terutama fungsi yang ketiga ada beberapa ahli yang menggunakan actuating sebagai penggerakan tetapi ada juga yang menggunakan actuating sebagai istilah pelaksanaan. Namun istilah tersebut digunakan untuk melaksanakan kegiatan sedangkan kata penggerakan merupakan wujud dari pelaksanaan kegiatan pekerjaan. Fungsi penggerak dan pelaksanaan dalam istilah lainnya yaitu motivating (membangkitkan motivasi), directing (memberikan arah), influencing (mempengaruhi) dan commanding (memberikan komando atau perintah).

Siagian (2012 : 36) menjelaskan bahwa fungsi Penggerakan (actuating) adalah : a) Menciptakan kerja sama yang lebih efisien. b) Mengembangkan kemampuan dan ketrampilan staf. c) Menumbuhkan rasa memiliki dan menyukai pekerjaan d) Mengusahakan suasana lingkungan kerja yang meningkatkan. motivasi dan prestasi kerja staf. e) Membuat organisasi berkembang secara dinamis sedangkan tahapan penggerakan (actuating) tindakan penggerakan dibagi dalam tiga tahap, yaitu: Memberikan semangat, motivasi, inspirasi atau dorongan sehingga timbul kesadaran dan kemauan para petugas untuk bekerja dengan baik. Wahyudi (1994:93) mengatakan," ada tiga tahapan dalam pelaksanaan program yaitu pada tahap perencanaan, pelaksanaan dan hasil pekerjaan. Salah satu dari ketiga tahapan tersebut adalah pengawasan prefentif yang berarti pengawasan yang dilakukan sebelum program dilaksanakan yaitu meliputi pengawasan dalam perencanaan program dan segala sesuatu yang dipersiapkan sebelum program dilaksanakan." Dengan demikian, pengawasan merupakan suatu kegiatan yang berusaha untuk mengendalikan agar pelaksanaan dapat berjalan sesuai dengan rencana dan memastikan apakah tujuan organisasi tercapai. Apabila terjadi penyimpangan di mana letak penyimpangan itu dan bagaimana pula tindakan yang diperlukan untuk mengatasinya.

Kadarisman (2012 : 172) mengatakan, "Pengawasan sumber daya manusia adalah kegiatan manajemen dalam mengadakan pengamatan terhadap : 1) Sumber daya manusia yang ada dalam organisasi 2) Sumber daya manusia yang benar-benar dibutuhkan organisasi 3) Pasaran sumber daya manusia yang ada dan memungkinkan 4) Kualitas sumber daya manusia yang dimiliki dan yang ada di pasaran tenaga kerja 5) Kemampuan individual dari setiap sumber daya manusia dalam organisasi 6) Upaya meningkatkan kemampuan sumber daya manusia dalam organisasi dan 7) Semangat kerja sumber daya manusia dan sebagainya. Pengawasan adalah kegiatan manajemen yang mengusahakan agar pekerjaan terlaksana sesuai dengan rencana yang ditetapkan atau hasil yang dikehendaki. Pengawasan adalah salah satu fungsi manajemen sepenuhnya adalah tanggung jawab setiap pimpinan pada tingkat manajemen karena bagian dari aktivitas dan tanggung jawab pimpinan dengan sasaran mewujudkan dan meningkatkan efisiensi, efektivitas, rasionalitas dan ketertiban dalam pencapaian tujuan dan pelaksanaan tugas-tugas organisasi. Dengan pengawasan pimpinan dapat mengambil tindakan pencegahan terhadap kemungkinan terjadinya penyimpangan, yang selanjutnya diarahkan pada tujuan yang telah ditetapkan. Pengawasan membantu penilaian apakah perencanaan, pengorganisasian, penyusunan personalia, dan pengarahan telah dilaksanakan secara efektif.

Undang-Undang Republik Indonesia Nomor 32 Tahun 2002 Tentang Penyiaran. Selanjutnya bahwa dalam Undang-Undang Republik Indonesia dimaksud pada pasal 8 ayat (9) menjelaskan, Lembaga Penyiaran Publik di tingkat pusat diawasi oleh Dewan Perwakilan Rakyat Republik Indonesia dan Lembaga Penyiaran Publik di tingkat daerah diawasi oleh Dewan Perwakilan Rakyat Daerah. Peraturan Pemerintah Nomor 12 Tahun 2005 Tentang Lembaga Penyiaran Publik Radio Republik Indonesia (LPP RI) Pasal 8 adalah sebagai berikut : a) Anggota dewan pengawas berjumlah 5 (lima) orang, 1 (satu) orang di antaranya ditetapkan menjadi ketua dewan pengawas berdasarkan keputusan hasil rapat anggota dewan pengawas. b) Dewan pengawas terdiri atas unsur RRI, masyarakat, dan pemerintah. c) Calon anggota dewan pengawas diusulkan oleh pemerintah kepada DPR RI berdasarkan masukan dari Pemerintah dan/atau masyarakat. d) Dalam melaksanakan tugas, dewan pengawas dibantu oleh sekretariat yang secara administratif berada di bawah dewan Direksi. Berdasarkan Peraturan Pemerintah tersebut di atas maka dewan pengawas berfungsi mewakili masyarakat untuk mengawasi pelakasanaan siaran Radio yang di siarkan pada masyarakat.

Selanjutnya Berdasarkan Peraturan Pemerintah tersebut pada pasal 1 ayat 5 dan 6 menjelaskan bahwa : a. Dewan Pengawas adalah organ lembaga penyiaran publik yang berfungsi mewakili masyarakat, pemerintah, dan unsur lembaga penyiaran publik yang menjalankan tugas pengawasan untukmencapai tujuan lembaga penyiaran publik. b. Dewan Direksi adalah unsur pimpinan lembaga penyiaranpublik yang berwenang dan bertanggung jawab terhadap pengelolaan lembaga penyiaran publik. Dengan demikian, pengawasan mengenai penyiaran adalah 
Dewan pengawas sesuai dengan Pasal 7 (a) dan (b) bahwa Dewan pengawas mempunyai tugas: a. menetapkan kebijakan umum, rencana induk, kebijakan penyiaran, rencana kerja dan anggaran tahunan, kebijakan pengembangan kelembagaan dan sumber daya, serta mengawasi pelaksanaan kebijakan tersebut sesuai dengan arah dan tujuan penyiaran. b. mengawasi pelaksanaan rencana kerja dan anggaran serta independensi dan netralitas siaran. Taufiq (2013:46) mengatakan bahwa Pengawasan menjadikan siklus fungsi manajemen lengkap dan membawa organisasi ke perencanaan. Makin jelas, lengkap dan terkoordinir rencana-rencana makin lengkap pula pengawasannya. Pengawasan terdiri dari penentuan standar-standar, pengawasan/ supervise kegiatan atau pemeriksaan, pembanding hasil dengan standa, serta kegiatan mengoreksi kegiatan atau standar. Berdasarkan pendapat ahli tersebut di atas, semakin baik pengawasan semakin baik pula hasil yang di capai, karena pengawasan mencegah dan mengantisipasi penyimpangan maupun penyelewengan, dengan demikian pengawasan sangat penting dalam sebuah organisasi apapun bentuk organisasinya, pengawasan dapat di terapkan dimana dan kapan saja.

Menurut Mukarom (2015 : 157) mengatakan,"Bahwa dalam rangka pelaksanaan pekerjaan dari pemerintahan yang telah di rencanakan, diperlukan pengawasan karena dengan pengawasan tersebut, tujuan yang akan dicapai dapat dilihat dengan berpedoman rencana yang telah ditetapkan terlebih dahulu oleh Pemerintah." Dengan demikian pengawasan pelayanan publik pemerintah akan efektif jika diimbangi dengan pengawasan yang ketat sehingga ruang gerak untuk melakukan penyimpangan maupun kekeliruan dapat diminimalisir. Selanjutnya bahwa fungsi pengimplementasian adalah sebagai berikut : 1. Mengimplementasikan proses kepemimpinan, pembimbingan, dan pemberian motivasi kepada tenaga kerja agar dapat bekerja secara efektif dan efisien dalam pencapaian tujuan. 2. Memberikan tugas dan penjelasan rutin mengenai pekerjaan menjelaskan kebijakan yang ditetapkan." Berdasarkan hal tersebut di atas, pengawasan merupakan pelaksanaan dari proses kepemimpinan dan pembimbingan agar karyawan dapat melaksanakan tugas dengan sebaik-baiknya serta dengan penuh tanggungjawab.

\section{METODE PENELITIAN}

Penelitian ini menggunakan penelitian deskriptif dengan pendekatan kualitatif. Penelitian deskriptif adalah suatu penelitian dengan tujuan untuk memperoleh gambaran secara sistematik, faktual dan akurat mengenai fakta-fakta yang terjadi dilapangan. Menurut Anggara (2015:21) Penelitian deskriptif adalah "Penelitian yang menjelaskan sesuatu yang menjadi sasaran penelitian secara mendalam. Artinya penelitian tersebut dilakukan untuk mengungkap segala sesuatu atau berbagai aspek dan sasaran penelitian." prosedur pemecahan masalah yang diselidiki dengan menggambarkan/melukiskan keadaan subjek/objek penelitian (seseorang), lembaga, masyarakat dan lain-lain) pada saat sekarang berdasarkan fakta-fakta yang nampak atau sebagaimana adanya." Dalam penelitian ini penulis akan meneliti tentang Manajemen Penyiaran Program Bahasa Daerah Radio Republik Indonesia Sintang. Subjek penelitian dalam penelitian ini dipilih dengan pertimbangan yang bersangkutan menguasai persoalan dan informasi yang sedang di teliti, dan mau memberikan data yang di perlukan sesuai dengan ruang lingkup penelitian". Menurut Kartiwa (2015 :85) bahwa, "Sumber data lapangan dapat berupa tokoh masyarakat, tokoh agama, aparat pemerintahan, dan sebagainya yang merupakan sumber data primer." Subjek penelitian ditetapkan dengan teknik porposive sampling (sampel bertujuan) artinya hanya terbatas pada mereka yang menguasai persoalan.

Adapun yang akan peneliti pilih sebagai subjek penelitian dalam penelitian ini adalah sebagai berikut : Kepala LPP RRI Sintang, Kasi Siaran, Penyiar Bahasa Daerah, Masyarakat (pendengar) Adapun teknik yang dipilih dalam penelitian dan pengumpulan data adalah Wawancara, Observasi, Studi Dokumentasi. Analisis data dalam penelitian ini menggunakan deskriptif data, yaitu data mentah yang telah terkumpul kemudian dideskripsikan dan digeneralisasikan serta ditarik kesimpulan secara kualitatif. Sehingga dapat memberikan jawaban sebagai solusi pemecahan masalah, penelitian dilakukan di Lembaga Penyiaran Publik RRI Sintang.

\section{HASIL PENELITIAN}

Perencanaan siaran Bahasa Daerah di sesuaikan dengan kebutuhan masyarakat di pedesaan menurut tradisi yang dapat melestarikan budaya daerah, bahasa yang digunakan disesuai dengan masing-masing daerah sehingga dapat di mengerti dan di fahami oleh masyarakat pendengar terutama yang masih sulit mengerti dalam menggunakan Bahasa Indonesia yang baik dan benar. Sejalan dengan hal tersebut di atas, bahwa siaran bahasa daerah dengan menggunakan bahasa daerah tertentu dapat di fahami karena bahasa daerah sehari-hari, oleh karena itu, masyarakat terutama pemuda dapat mengerti budaya-budaya maupun tradisi yang dilakukan oleh orang tua maupun nenek moyangnya secara turun-temurun. 
Berdasarkan pokok pemikiran di atas, bahwa bahasa daerah sangat penting untuk di fahami terutama masyarakat setempat yang tidak dilahirkan di tempat tersebut tetapi orang tuanya berasal dari daerah yang bersangkutan, biasanya tidak memahami dengan baik tradisi yang di warisi oleh leluhurnya, dengan adanya siaran bahasa daerah membantu menterjemahkan hal-hal yang berkaitan dengan pelestarian budaya daerah dan adat-istiadat serta tradisi di daerah, terutama di pedesaan. Siaran bahasa daerah membantu masyarakat selaku pendengar untuk memahami budaya dan tradisi masyarakatnya sendiri karena penyiarnya adalah orang yang betul-betul memahami budaya dan tradisi sukunya sendiri serta orang yang memiliki pengaruh dalam masyarakat tersebut. Dengan demikian, melalui siaran dipahami sepenuhnya oleh masyarakat selaku pendengar serta bermanfaat dalam mengembangkan dan melestarikan budaya maupun tradisi masyarakat yang bersangkutan. Sesuai hal tersebut di atas, dengan memahami budaya dan adat-istiadat sehingga masyarakat dapat menghargai kebudayaan sendiri serta meningkatkan ke arifan lokal dalam masyarakat tersebut.

Siaran bahasa daerah sangat bermanfaat bagi masyarakat khususnya masyarakat di pedesaan terutama masyarakat yang tidak memahami sepenuhnya bahasa Indonesia yang digunakan pada saat siaran yang bersifat umum, oleh karena itu bahwa masyarakat merasa senang dapat mendengar siaran bahasa daerah (lokal) yang ada saat ini. Melalui hasil wawancara tersebut itu berarti respon masyarakat terhadap siaran bahasa daerah sangat baik, dengan demikian siaran tersebut perlu di rencanakan dengan baik sehingga menghasilkan sesuatu yang lebih baik. Materi yang disiarkan belum terjadwal dengan baik tertutama pokok bahasan, selama ini hanya di berikan sepenuhnya pada penyiar sepenuhnya mengatur materi apa yang ingin di sampaikan, hal ini di sebabkan bahwa tidak semua pegawai dapat memahami bahasa daerah dengan baik. Namun demikian bahwa kedepannya siaran bahasa daerah materi yang akan di siarkan terjadwal sehingga menjadi teratur dan terarah dari awal sampai akhir dalam satu tahun.

Pengaturan jadwal siaran itu di sesuaikan dengan program LPP RRI Pusat dan dilaksanakan oleh Kepala Bagian penyiaran itu sebabnya siaran bahasa daerah tidak dapat dilakukan melebihi satu jam karena harus bergabung dengan siaran nasional yang di siarkan secara langsung RRI Pusat yang berkedudukan di Jakarta, serta diteruskan oleh siaran radio-radio milik pemerintahan maupun non pemerintahan (Radio swasta. Bertitik tolak dari pernyataan di atas bahwa masyarakat kota yang penuh dengan kesibukan lebih banyak mengetahui berita-berita melalui berita-berita online, sehingga RRI juga membuat berbagai terobosan untuk mampu bersaing dengan media-media lainnya melalui program Radio online atau RRI Play Go, RRINet dan lain-lain, dengan demikian siaran RRI dapat dimonitor dimana dan kapan saja, namun program tersebut belum banyak di ketahui oleh masyarakat pendengar sehingga perlu diinformasikan pada masyarakat baik masyarakat kota maupun pedesaan tentang program radio online RRIPlay Go dan RRINet.

Sejalan dengan hal tersebut di atas, program RRIPlay maupun RRINet dapat di akses melalui handphone melalui aplikasi RRIPlay dan RRINet, program tersebut membuat masyarakat dapat memonitor siaran RRI khususnya RRI Sintang. Program tersebut memang belum banyak diketahui oleh masyarakat pendengar sehingga program ini perlu di sampaikan pada masyarakat luas dalam rangka meningkatkan mutu pelayanan siaran RRI. Dengan demikian bahwa siaran RRI programnya tersusun dengan baik tergantung kemampuan manajemen penyiaran dalam mengelola jadwal bahkan mungkin sampai pada materi siaran, selain kemampuan menyusun jadwal acara yang di siarkan khsususnya siaran lokal juga dipadukan dengan siaran secara nasional sebab dalam jam tertentu atau acara tertentu bahwa berita yang di siarkan sentral dari RRI pusat, oleh karena itu, RRI selain menayangkan siaran lokal juga siaran nasional, sebab jadwal acara RRI dipadukan dengan siaran secara sentral dari Jakarta.

Namun dalam hal tertentu bahwa RRI di tingkat Daerah di berikan kewenangan untuk menyusun acara dan membuat acara sesuai dengan kebutuhan daerah. Siaran tersusun dengan baik berdasarkan panduan siaran RRI Pusat secara sentral khususnya siaran nasional tetapi siaran khusus lokal RRI di daerah di berikan kewenangan mengaturnya sesuai kebutuhan masyarakat di daerah, itu sebabnya bahwa siaran bahasa daerah dibutuhkan dalam rangka meningkatkan dan melestarikan bahasa daerah serta tradisi maupun adat-istiadat masyarakat di daerah yang bersangkutan. Sejalan dengan hal tersebut bahwa siaran bahasa daerah di siarkan RRI Sintang dalam rangka menjawab kebutuhan masyarakat daerah untuk mengangkat nilai-nilai dan melestarikan bahasa daerah, pada saat ini generasi muda tidak banyak yang memahami adat-istiadat dan tradisi daerahnya masing-masing hal ini di pengaruhi oleh arus komunikasi dan transformasi yang lebih cepat berkembang mempengaruhi pemuda bahkan anakanak, selain itu media komunikasi menampilkan berbagai macam program seperti video game yang pada akhirnya mempengaruhi aktivitas pemuda, sementara program video game yang ada di handphone tidak menampilkan bahasa daerah 
maupun tradisi masyarakat, tentu hal ini menjadi tantangan tersendiri bagi suatu masyarakat, bangsa dan Negara bahkan sampai saat ini generasi muda khususnya masih terdapat pemuda yang tidak tahu mengenai tradisi suku masing-masing.

Terutama siaran bahasa daerah menjelaskan bahwa siaran yang di sajikan oleh RRI sangat bermanfaat bagi masyarakat, oleh karena itu RRI dalam melakukan penyiaran terutama yang dilakukan terlebih dahulu adalah melakukan perencanaan penyiaran serta tema siaran yang di sampaikan sehingga susunan acaranya teratur dan mudah di pahami oleh pendengarnya.

Siaran bahasa daerah di tampilkan terutama sesuai dengan kebutuhan masyarakat tentang pentingnya memahami bahasa daerah masing-masing khususnya masyarakat pedesaan yang tinggal di perkotaan, selain itu bahwa siaran bahasa daerah untuk melestarikan dan mengembangkan kebudayaan serta mengangkat nilai-nilai dan adat-istiadat budaya masing-masing. Siaran bahasa daerah dilakukan atas dasar permintaan masyarakat yang untuk mengisi acara di RRI Sintang, oleh karena itu, RRI Sintang menyambut baik dan memberikan kesempatan seluas-luasnya pada masyarakat yang ingin mengisi acara, namun tetap berdasarkan pada jadwal yang telah di tentukan.

Materi penyiaran bahasa daerah di serahkan sepenuhnya pada penyiar dalam menyusun materi yang akan di siarkan, sebab pegawai RRI tidak mengerti sepenuhnya urutan peristiwa materi yang di sampaikan. Selanjutnya hal ini berarti RRI Sintang membuat dan merencanakan jadwal siaran sementara materi siaran khususnya bahasa daerah itu tergantung pada penyiar masing-masing, namun demikian Kepala Bagian penyiaran memberikan kesempatan pada pendengar untuk memberikan kritikan, saran dan masukan demi perbaikan mutu siaran. Dalam melakukan siaran kadang-kadang pemakaian katakata yang di gunakan keliru dengan Bahasa Indonesia sehingga tidak jarang juga menggunakan Bahasa Indonesia pada hal siaran bahasa daerah, oleh karena itu penyiar membawa catatan untuk mengartikan kata-kata yang akan di sampaikan, karena tidak mudah juga mengartikan bahasa daerah terutama menyesuaikan bahasa masyarakat setempat walaupun penyiarnya sendiri menggunakan bahasa tersebut karena dipengaruhi juga oleh penggunaan Bahasa Indonesia. Sejalan dengan hal tersebut maka penyiar bahasa daerah sebelum menyampaikan materi siaran terlebih dahulu pengantarnya wajib menggunakan bahasa Indonesia, hal ini sudah di bahas dalam diskusi pada peringatan Hari Ulang Tahun RRI tahun 2018 di RRI Sintang.
Pengorganisasian merupakan salah satu fungsi manajemen yang kedua setelah perencanaan, oleh karena itu, sebuah organisasi memiliki sebuah struktur organisasi sebagai bentuk penjelasan mengenai tugas-tugas dan pembagian tugas sesuai dengan bidang tugas masing-masing pegawai/ karyawan, dengan demikian RRI sebagai sebuah organisasi di dalamnya adalah kumpulan orang-orang yang berinteraksi dan berkomunikasi dalam melaksanakan tugas, tentunya memainkan peranan masing-masing. Langkah-langkah proses pengorganisasian diperlukan dalam rangka merinci seluruh pekerjaan yang harus dilaksanakan untuk mencapai tujuan organisasi, selain adanya rincian mengenai langkah-langkah tersbut di atas pengorganisasian juga membagi beban kerja ke dalam kegiatan-kegiatan yang secara logis dan memadai dapat dilakukan oleh para pegawai dengan mengkombinasikan secara efektif dan efisien dalam mengambil langkah-langkah penyesuaian untuk mempertahankan atau meningkatkan efektivitas sebuah pekerjaan.

Dengan demikian, pembagian tugas sangat penting untuk pengelolaan sebuah organisasi tujuan adalah membagi beban pekerjaan menjadi kegiatankegiatan yang secara logis dapat dilaksanakan oleh personel masing-masing sehingga masing-masing fungsi dapat menjalankan tugasnya dengan baik. Pengadaan dan pengembangan suatu mekanisme untuk mengkoordinasikan pekerjaan para anggota organisasi menjadi kesatuan yang terpadu dan harmonis. Pelaksanaan tugas dan pekerjaan masing-masing bagian dan antar bagian di RRI Sintang melakukan koordinasi, sehingga dalam pelaksanaan siaran tidak berjalan sendiri-sendiri, dengan demikian program dan rencana program serta pelaksanaan siaran sudah terjadwal dengan baik khususnya siaran yang bersifat umum sementara siaran bahasa daerah di serahkan sepenuhnya pada penyiar untuk menyusun materi yang akan di siarkan. Namun demikian pelaksanaannya juga sudah dilakukan koordinasi dengan pihak manajemen penyiaran sehingga tidak tumpang tindih pekerjaan.

Salah satu bentuk dari koordinasi adalah melalui diskusi bersama jajaran pegawai RRI baik formal maupun non fornal bahkan dilakukan evaluasi terhadap program yang di sajikan oleh RRI dengan mengundang para pemerhati siaran, serta anggota penyiar maupun Perguruan Tinggi diharapkan memberikan masukan pada RRI tentang pelaksanaan siaran, sehingga RRI selalu membina kerja sama dengan pihak lain masyarakat, pemerintah dan swasta termasuk Perguruan Tinggi. Siaran dan acara yang di tampilkan oleh RRI sudah sesuai dengan kebutuhan masyarakat, hal ini menunjukan bahwa berdasarkan tugas dan 
fungsinya RRI merupakan milik publik wajib memberikan pelayanan pada masyarakat dengan sebaik-baiknya terutama masyarakat pedesaan yang dapat menikmati siaran RRI sebab siaran RRI dapat di monitor oleh masyarakat pedesaan, sementara masyarakat di perkotaan lebih banyak menikmati acara TV dan berita majalah online. Selain hal tersebut bahwa RRI menyajikan beritaberita Daerah maupun berita nasional, secara organisasi bahwa RRI memliki susunan acara tidak berbeda dengan RRI pusat, namun demikian RRI di daerah diperkenankan menambah jenis siaran selain yang telah di tentukan oleh RRI Pusat karena di sesuaikan dengan kebutuhan daerah, asalkan penyampaian berita tersebut tidak bertabrakan dengan siaran secara nasional. Sebab berita nasional dilakukan secara serentak oleh seluruh Radio Republik Indonesia secara sentral dari

Radio Republik Indonesia yang berkedudukan di Jakarta sebagai organisasi pusat RRI. Pembagian tugas dan pekerjaan pegawai RRI sudah di atur berdasarkan bidang tugas masingmasing sehingga cara kerja dalam menyajikan berita maupun dalam pelaksanaan tugas pelayanan berdasarkan sistem yang telah di tetapkan, dengan demikian tidak ada jadwal yang tidak terisi dengan acara siaran maupun acara dialog khusus atau siaran langsung. Sesuai dengan hasil wawancara tersebut di atas berarti pembagian tugas sudah di jalankan berdasarkan bidang tugas masing-masing, tujuan pembagian tugas tersebut adalah untuk memudahakan pelaksanaan pekerjaan, dan tidak terjadi tumpang tindih pekerjaan, sehingga pekerjaan di laksanakan dengan teratur dan tersusun dengan baik.

Namun demikian dalam pelaksanaan tugas bukan berarti tidak ada hambatan terutama pada saat acara sedang berlangsung misalnya listrik padam sehingga siaran yang di sampaikan pada publik mengalami kendala, dengan demikian memerlukan bagian teknik untuk cepat mengambil tindakan agar acara siaran tetap berlanjut. RRI Sintang sudah memiliki genset sendiri dengan berbagai upaya sehingga hal tersebut tidak terganggu jika listrik padam. Dalam melakukan penyiaran bahasa daerah bukan berarti penyiar bahasa daerah berstatus sebagai pegawai negeri di RRI Sintang, tetapi bekerja berdasarkan kerelaan untuk memberikan informasi pada masyarakat terutama untuk masyarakat dari daerah yang bersangkutan untuk menyampaikan tentang tradisi maupun adat-istiadat masyarakat setempat, dengan demikian siaran bahasa daerah merupakan bagian dari pengembangan dan pelestarian budaya daerah maupun kebudayaan nasional, sebab kebudayaan daerah merupakan bagian yang integral dari kebudayaan nasional. Selanjutnya bahwa kebudayaan nasional harus dilestarikan dan dikembangkan oleh seluruh masyarakat Indonesia, oleh karena itu sangat tepat jika melalui RRI penyampaian berita serta cara-cara mengembangkan kebudayaan tersebut dapat diorganisir dengan baik dan di sebarkan melalui media seperti radio maupun TV sehingga masyarakat dapat mendengar dan melihat secara langsung pengembangan kebudayaan serta nilainilai tradisi dalam masyarakat dapat di kembangkan dan di lestrarikan secara terus-menenrus. Sehubungan dengan hal tersebut, pemimpin memegang peranan penting dalam pengembangan organisasi, karena organisasi dapat merumuskan tujuan serta pemberdayaan manusia. Pemimpin yang memiliki cara pandang luas dan ke masa depan sesuai kepentingan perubahan diperlukan dalam organisasi adalah transformasional, yaitu kepemimpinan yang memiliki gaya memberdayakan SDM, melayani, instruktur, koordinator dan selalu memberikan bimbingan dalam pelaksanaan tugas pada bawahannya.

Pelaksanaan penyiaran sudah di atur materi yang akan di sampaikan sesuai dengan jadwal yang sudah di tentukan, oleh karena itu penyiar diharapkan mempersiapkan diri dengan sebaik-baiknya. Hal ini berarti penyiar sudah memahami materi yang akan di sampaikan pada masyarakat khususnya pendengar, dengan demikian diharapkan bahwa sumber daya manusia yang profesional dapat memberikan penambahan nilai yang berkaitan dengan kemampuan mengelola pesan atau berita yang disampaikan memberikan pengaruh bagi pendengar sehingga dapat menjadi agen perubahan dan pembaharuan bagi masyarakat secara keseluruhan. Aplikasinya dengan menciptakan hal-hal yang berkaitan dengan pembaharuan organisasi melalui adanya agen perubahan, mampu mengidentifikasi dan menemukan masalah yang dihadapi serta membantu memecahkan persoalan tersebut, oleh karena itu RRI harus mampu membangun hubungan kepercayaan, memecahkan masalah dan tetap netral dalam menjalankan tugas sebagai lembaga publik. Pelaksanaan penyiaran tidak di bekali dengan pelatihan serta tidak ada ketentuan sebagai penyiar bahasa daerah harus memiliki keahlian dibidang khusus penyiaran, tetapi hanya sebagai pengisi acara sebab penyiar bahasa daerah bukan pegawai RRI dan tidak terikat. Sejalan dengan hal tersebut di atas, bahwa pegawai RRI baik tenaga kontrak maupun pegawai tetap dalam arti pegawai yang sudah di angkat menjadi Pegawai Negeri Sipil di RRI berprofesi sebagai penyiar memiliki kemampuan dalam menyampaikan informasi kepada masyarakat namun demikian rata-rata pegawai di RRI Sintang rata-rata masih sebagai tenaga kontrak atau honorer mengingat pengangkatan pegawai negeri sipil di RRI 
pengangkatannya langsung dari pemerintah pusat, dalam arti bahwa pegawai negeri sipil di RRI melaksakan lamaran dan penerimaan hanya di lakukan di RRI pusat yang berkedudukan di Jakarta sehingga penyiar yang ada saat ini lebih banyak adalah tenaga kontrak.

Standar kelayakan sumber daya manusia di RRI Sintang bahwa lembaga penyiaran menggunakan sumber daya manusia yang memiliki pengetahuan, keterampilan, keahlian, kompetensi, dan kualifikasi sesuai standar kelayakan profesi penyiaran, sedangkan untuk menduduki jabatan yang membutuhkan kemampuan teknis atau keahlian khusus harus memiliki sertifikasi dari organisasi profesi lembaga penyiaran, lembaga pendidikan/pelatihan, atau institusi terkait yang relevan, dan jabatan dilembaga penyiaran yang harus memiliki sertifikasi adalah program director, newsdirector, musicdirector, produser, dan teknisi. Selain hal tersebut penyiar bahasa daerah juga tidak di ijinkan menyampaikan informasi yang sifatnya mengajak masyarakat dalam mendukung caleg atau Kepala Daerah tertentu sebab, RRI merupakan lembaga publik yang bersifat independen. Sejalan dengan hal tersebut di atas, bahwa RRI berfungsi menyampaikan informasi pada masyarakat serta memberikan pelayanan bagi masyarakat, oleh karena itu, peningkatan mutu informasi maupun berita yang di sajikan adalah untuk perkembangan dan kemajuan masyarakat atau kemajuan bangsa dan Negara. Dengan demikian, eksistensi RRI adalah untuk kepentingan masyarakat menyajikan hal-hal yang berkaitan dengan kebutuhan masyarakat. Sejalan dengan penjelasan di atas, maka dalam pelaksanaan program penyiaran bahasa daerah sesuai dengan jadwal yang telah direncanakan dan dibuat oleh bagian penyiaran.

Pelaksanaan siaran sudah ada jadwal masing-masing hanya persoalannya adalah berkaitan dengan lamanya siaran dan waktu pelaksanaan salah satunya adalah pelaksanaan siaran bahasa dayak desa dan dayak lebang berbagi waktu kalau minggu ini jadwal siaran bahasa desa maka minggu berikutnya siaran bahasa dayak lebang, seharusnya bisa di bedakan harinya tidak perlu menunggu minggu berikutnya, namun karena jadwal siaran padat dan sistematis sehingga dilaksanakan sebagaimana dimaksud di atas, sementara siaran bahasa daerah lain tidak demikian, alasannya adalah bahasa daerah yang lainnya sudah lama mengisi acara tersebut.

Selanjutnya bahwa program pelaksanaan siaran bahasa daerah berdasarkan permintaan masyarakat yang ingin mengetahui bahasa daerah serta budaya maupun adat-istiadat di daerah yang bersangkutan, pemerintah juga mendukung pelestarian budaya daerah yang merupakan kearifan lokal yang harus di kembangkan, sebab budaya dan bahasa daerah tidak dapat dipisahkan dari budaya nasional, sejalan dengan hal tersebut maka sesuai dengan amanat Undang-Undang bahwa pemerintah memajukan kebudayaan nasional, harapannya adalah agar masyarakat memahami dan mengerti serta dapat memfungsikan budaya masing-masing sesuai dengan bagaimana yang seharusnya. Melalui siaran bahasa daerah budaya dan adat-istiadat itu perlu dikembangkan tetapi budaya yang tidak sesuai dengan perkembangan zaman tidak masalah kalau itu ditinggalkan oleh masyarakat, tanpa menyebut budaya yang seperti apa yang tidak cocok dengan perkembangan masyarakat, tetapi umumnya bahwa semua tradisi dan adat-istiadat rata-rata masih relevan dengan perkembangan zaman, dalam arti bahwa adat-istiadat dan tradisi layak untuk di kembangkan dan dilestarikan dengan demikian bahwa budaya merupakan kekayaan bangsa. Dengan demikian, budaya bagi suatu bangsa sangat penting sebagai penopang karakter masyarakat maupun suatu bangsa, apa lagi budaya Indonesia yang di kenal dengan sopan santun dan ramah tamah.

Pelaksanaan siaran bahasa daerah tidak mengalami persoalan walaupun memang penyiarnya tidak dibekali dengan keterampilan khusus tetapi umumnya penyiar dapat menyampaikan dengan baik dan dapat dipahami oleh pendengar khususnya masyarakat yang ada di pedesaan walaupun penyiar sendiri mengakui bahwa awal melaksanakan siaran di RRI memang sangat kaku sehingga perlu di pandu oleh pegawai RRI untuk memberikan petunjuk penggunaan istrumen yang digunakan untuk melaksanakan penyiaran. Namun demikian lama kelamaan dan seringnya melakukan penyiaran pada gilirannya tidak kaku lagi dan terbiasa walaupun harus latihan sendiri di rumah sebelum melakukan siaran. Siaran yang di sampaikan semuanya penting, masyarakat dapat memilah materi siaran mana yang menunjang kegiatan dan aktivitas masing-masing serta dapat dikembangkan sesuai profesi masing-masing, sebab RRI hadir di tengah-tengah masyarakat adalah untuk kepentingan dan pelayanan pada masyarakat sebagai lembaga publik yang independen serta tidak memihak kelompok manapun dalam pelaksanaan tugasnya dan tidak dibenarkan bahwa pegawai RRI melakukan politik praktis. Dengan demikian, melalui keberadaan yang independen maka RRI dapat di percaya oleh masyarakat dalam menyampaikan pesan-pesan baik berupa pembangunan maupun program dan kebijakan pemerintah, sehingga RRI sebagai media atau sebagai perekat persatuan bangsa dan Negara sangat terpercaya dan dicintai oleh masyarakat. Selanjutnya bahwa pelaksanaan siaran tentu sejalan dengan perencanaan program, sebab 
perencanaan yang baik adalah mudah dilakukan dan dikerjakan termasuk oleh yang melakukan perencanaan program.

Pengawasan penyiaran Bahasa Daerah dilakukan sama dengan penyiar program siaran lainnya, dalam arti tidak ada siaran di RRI yang tidak dilakukan pengawasan, sebab pengawasan di RRI memiliki tujuan agar siaran yang di sampaikan pada publik tidak menyimpang dari konteks yang sebenarnya. Dengan demikian pengawasan memiliki arti penting dalam manajemen siaran sehingga informasi atau pesan yang di sampaikan pada masyarakat luas dapat mencapai sasaran yang diinginkan secara efektif dan efisien.

\section{KESIMPULAN DAN SARAN}

Perencanaan Penyiaran Bahasa Daerah sudah dilakukan dan selalu berkoordinasi dengan koordinator (kasubsi perencanaan program) di sesuaikan dengan kebutuhan masyarakat baik dari segi isi siaran maupun sasaran penyiaran. Secara organisasi bahwa Radio Republik Indonesia bekerja sesuai pembagian tugas dalam pelaksanaan penyiaran antara penyiar dengan Kasubsi perencanaan program maupun dalam memberikan pelayanan pada masyarakat. Pelaksanaan penyiaran tersebut sesuai dengan perencanaan yang telah di tentukan dan mengacu pada jadwal pelaksanaan siaran. Pengawasan penyiaran dilakukan oleh Kasi Penyiaran baik isi siaran maupun ketentuan penyiaran, lainnya. Selanjutnya ada beberapa saran yang dapat penulis ajukan, Perencanaan Penyiaran Bahasa Daerah sudah direncanakan dengan baik, diharapkan pada penyiar khususnya penyiar bahasa daerah merencanakan materi yang akan disiarkan, hendaknya isi siaran agar tersusun dengan baik sesuai perencanaan yang telah ditentukan. Pengawasan penyiaran sebaiknya dipertahankan dan ditingkatkan dengan melibatkan berbagai pihak selaku pemerhati penyiaran selain Kasi penyiaran sehingga siaran yang di sampaikan menghasilkan pesan yang baik pada publik sasaran.

\section{DAFTAR PUSTAKA}

Anggara, Sahaya. 2015. Metode Penelitian Administrasi. Bandung: Pustaka Setia. Bungin, Burhan. 2015. Metodologi Penelitian Kuailitatif, Aktualisasi Metodologis kea rah Ragam Varian Kontemporer. Jakarta : RajaGrafindo Persada.

Danim, Sudarwan. 2002. Menjadi Peneliti Kualitatif, Ancaman Metodolog, Presentasi dan Publikasi Hasil Penelitian Untuk Mahasiswa dan peneliti Pemula Bidang Ilmu-Ilmu Sosial, Pendidikan dan Humaniora. Bandung: Pustaka Setia. Gitosudarmo dan Sudita. 2000. Perilaku Organisasi. Yogjakarta: BPFE.

Handayaningrat, Soewarno. 2007. Pengantar Studi Ilmu Administrasi dan Management. Jakarta: Bina Aksara. Jeffrey. 1991. Manajamen Proyek. Yogyakarta : Kanisius.

Kadarisman. 2012. Manajemen Pengembangan Sumber Daya Manusia. Jakarta : PT.Raja Grafindo.

Kartiwa, Asep. 2015. Metode Penelitian Administrasi. Bandung : CV. Pustaka Setia.

Manullang, M. 2009. Dasar-Dasar Manajemen. Yogyakarta: Gajah Mada University Press.

Masduki. 2004.Menjadi Broadcaser Profesional, Yogyakarta: PT. Lkis Plangi Aksara.

Masduki. 2011. Petunjuk Pelaksanaan dan Petunjuk Teknis Penyelenggaraan Siaran Program Berjaringan Lembaga Penyiaran Publik RRI. Direktorat Program dan Produksi LPP RRI Tahun 2011

Morissan. 2009. Manajemen Media Penyiaran Strategi Mengelola Radio dan Televisi. Jakarta: Kencana

Mukarom, Zaenal dkk. 2015. Manajemen Pelayanan Publik. Bandung : Pustaka Setia.

Nawawi, H. 2001. Manajemen Sumberdaya Manusia, Gajahmada Universitas Press. Rusdiana dkk. 2014. Sistem Informasi Manajemen. Bandung : Pustaka Setia

Siagian, SP. 2015. Manajemen Sumber Daya Manusia. Jakarta: Bumi Aksara

Siagan SP. 2012. Fungsi-fungsi manajemen. Jakarta: bumi aksara.

Silalahi Ulbert. 2002. Studi Tentang Ilmu Administrasi Konsep, Teori dan Dimensi. Bandung : Sinar Baru Algensindo. 
Sugiyono. 2017. Metode Penelitian, Kuantitatif, Kualitatif dan $R$ dan $D$. Bandung : Afabeta

Syamsi, Ibnu. 1998. Pokok-Pokok Organisasi dan Manajemen. Jakarta : Bina Aksara. Soeharyo. S dkk. 2006. Sistem Penyelenggaraan Pemerintahan NKRI. Jakarta : LAN-RI

Taufiq, Rohman. 2013. Sistem Informasi Manajemen, Konsep Dasar, Analisis dan Metode Pengembangan.Yogyakarta : $\quad$ Graha Ilmu. 